\title{
DERMATOLOGICAL ADVERSE EFFECTS OF CHEMOTHERAPEUTIC AGENTS: EXPERIENCE FROM A TERTIARY CENTRE
}

\author{
Parvaiz Anwar Rather ${ }^{1}$, M. Hussain Mir², Sandeep Kaul³, Vikas Roshan', Jilu Mathews ${ }^{5}$, Bandu Sharma ${ }^{6}$ \\ ${ }^{1}$ Lecturer, Department of Dermatology, GMC, Jammu, Jammu \& Kashmir, India. \\ ${ }^{2}$ Consultant, Department of Oncology, Narayana Superspeciality Hospital, Katra, Jammu, Jammu \& Kashmir, India. \\ ${ }^{3}$ Consultant, Department of Surgical Oncology, Narayana Superspeciality Hospital, Katra, Jammu, Jammu \& Kashmir, India. \\ ${ }^{4}$ Consultant, Department of Radiation Oncology, Narayana Superspeciality Hospital, Katra, Jammu, Jammu \& Kashmir, India. \\ ${ }_{5}^{5}$ Senior Nursing In Charge, Department of Oncology, Narayana Superspeciality Hospital, Katra, Jammu, Jammu \& Kashmir, India. \\ ${ }^{6}$ Senior Nursing In Charge, Department of Oncology, Narayana Superspeciality Hospital, Katra, Jammu, Jammu \& Kashmir, India.
}

\begin{abstract}
BACKGROUND

Chemotherapeutic agents, both conventional and new targeted therapy, are known to cause diverse side effects related to skin, hair, mucous membranes and nails, collectively called 'dermatological adverse effects`. But such association in literature is mostly confined to case reports/case series and small number of published papers.

The aim of this study is to look for dermatological adverse effects and the most common culprit agents, with the objective that the oncologist and dermatologist team remain vigilant and adopt rational management protocol in their management to circumvent the morbidity and long-term toxicity as it involves the cosmetic appearance of long-term cancer survivor.
\end{abstract}

\section{MATERIALS AND METHODS}

This prospective hospital-based descriptive study was conducted jointly by the dermatologist and oncology team over a period of more than one year in a specialised tertiary centre on oncology patients, who developed dermatological side effects after initiation of anti-cancer drugs.

\section{RESULTS}

Out of 125 patients studied, dermatological adverse effects of varying duration were noticed in 27 patients (21.6\%), with overall 45 side effects manifestation. Most common among cutaneous manifestations were anagen and telogen effluvium, followed by diffuse hyperpigmentation, xerosis and hand-foot syndrome. Nail discolouration was the most notable nail change, leukonychia being more common than hyperpigmentation, and the most common oral mucosa manifestation was oral mucositis.

\section{CONCLUSION}

Although dermatological adverse effects due to chemotherapeutic agents is commonly recognised, yet most of the times the features are not of such serious nature as to warrant withdrawal of the therapy. But a thorough knowledge is essential to alleviate the apprehension arising as a result of it and to improve the overall outcome of patients.

\section{KEYWORDS}

Chemotherapeutic Agents; Cutaneous Manifestations; Nail Changes; Mucositis; Targeted Drugs.

HOW TO CITE THIS ARTICLE: Rather PA, Mir MH, Kaul S, et al. Dermatological adverse effects of chemotherapeutic agents: Experience from a tertiary centre. J. Evolution Med. Dent. Sci. 2017;6(51):3911-3916, DOI: 10.14260/Jemds/2017/846

\section{BACKGROUND}

The association of internal malignancies with mucocutaneous, hair and nail involvement, collectively called dermatological involvement, is an established fact. Similarly, anti-cancer drugs, which usually affect rapidly growing cells, including skin, hair follicles and nail matrix are frequently responsible for the dermatological toxicities of chemotherapeutic agents.1,2,3

This is validated in the literature mostly in the form of case reports, which inspired us to conduct a study, with the aim to identify the most common dermatological adverse

Financial or Other, Competing Interest: None.

Submission 20-05-2017, Peer Review 14-06-2017,

Acceptance 20-06-2017, Published 24-06-2017.

Corresponding Author:

Dr. Parvaiz Anwar Rather,

Quarter No. D3,

Old Block, Medical Enclave,

Near KC Theatre, Bakshi Nagar-180001,

Jammu, Jammu and Kashmir, India.

E-mail: parvaizanwar@gmail.com

DOI: $10.14260 /$ jemds $/ 2017 / 846$ effects and the most common chemotherapeutic agents causing these adverse effects. Knowledge of dermatological side-effects of newer anti-cancer drugs will enable the dermatologist and oncologist team in their rational management, obviating the need of withdrawing these potentially life-prolonging medications.

\section{MATERIALS AND METHODS}

The prospective hospital-based descriptive study was conducted jointly by a dermatologist and oncology team of a specialised tertiary centre. Oncology patients, both outdoor and inpatient, put on various types of chemotherapeutic regimens over a period of more than one year, were thoroughly evaluated for demographic details, type of malignancy and therapeutic options, and also screened for associated dermatological involvement by short history and a quick examination, in accordance with a questionnaire prepared by the dermatologist. Patients who developed dermatological side effects after initiation of anti-cancer drugs were referred to the dermatologist. Dermatological diagnosis was made from a detailed history, dermatological examination and need based relevant investigations, including skin biopsy for histopathological examination, and 
recorded in a format after a proper written consent. Patients with dermatological involvement prior to the start of chemotherapy and those on radiotherapy were excluded from the study.

\section{RESULTS}

125 patients with various types of malignancies were studied for chemotherapy related dermatological adverse effects. Out of these, 66 were male and 59 were female.

The age of the patients ranged from 16-79 years, with average age of 53.74 ( \pm SD 13.16). 68 patients (54.4\%) were in age group 41-60 years, followed by $39(31.2 \%)$ in $\geq 61$ years age group. There were 16 patients (12.8\%) in 21-40 years and $2(1.6 \%)$ in $\leq 20$ years age group. This is summarised in Table 1.

\begin{tabular}{|c|c|c|}
\hline $\begin{array}{c}\text { Age Group } \\
\text { (Years) }\end{array}$ & $\begin{array}{c}\text { All the Oncology } \\
\text { Patients (n=125) }\end{array}$ & $\begin{array}{c}\text { With Dermatological } \\
\text { Adverse Effects (n=27) }\end{array}$ \\
\hline$\leq 20$ & 2 & 0 \\
\hline $21-40$ & 16 & 4 \\
\hline $41-60$ & 68 & 15 \\
\hline$\geq 61$ & 39 & 8 \\
\hline Total & $\mathbf{1 2 5}$ & $\mathbf{2 7}$ \\
\hline \multicolumn{2}{|c|}{ Table 1. Age Groups of All Oncology Patients and } \\
those with Dermatological Adverse Effects \\
\hline
\end{tabular}

Most of the patients, 24, had gastrointestinal tract malignancies, followed by breast, female reproductive tract (including cervical and ovarian), oral cavity, haematologic, lung and lymphoma, found in $22,17,14,12,10,8$ patients respectively. Other types of malignancies are summarised in Table 2 .

\begin{tabular}{|c|c|c|c|}
\hline Organ System & Sub-part & $\begin{array}{c}\text { No. of } \\
\text { Patients } \\
\end{array}$ & $\begin{array}{c}\text { Total } \\
(n=125)\end{array}$ \\
\hline \multirow{6}{*}{ Gastrointestinal } & Gastro-oesophageal & 11 & \multirow{6}{*}{24} \\
\hline & Colon & 7 & \\
\hline & Pancreas & 2 & \\
\hline & Gallbladder & 2 & \\
\hline & Anal canal & 1 & \\
\hline & $\begin{array}{c}\text { Stromal tumour } \\
\text { (GIST) }\end{array}$ & 1 & \\
\hline Breast & & 22 & 22 \\
\hline \multirow{3}{*}{$\begin{array}{c}\text { Female } \\
\text { reproductive } \\
\text { system }\end{array}$} & Cervix & 9 & \multirow{3}{*}{17} \\
\hline & Ovary & 7 & \\
\hline & $\mathrm{H}$ mole & 1 & \\
\hline \multirow{2}{*}{ Oral cavity } & Buccal mucosa & 9 & \multirow{2}{*}{14} \\
\hline & Tongue & 5 & \\
\hline \multirow{5}{*}{ Haematologic } & CML & 4 & \multirow{5}{*}{12} \\
\hline & AML & 3 & \\
\hline & Multiple myeloma & 3 & \\
\hline & ALL & 1 & \\
\hline & CLL & 1 & \\
\hline $\begin{array}{c}\text { Lungs \& pleural } \\
\text { cavity }\end{array}$ & & 10 & 10 \\
\hline \multirow{3}{*}{ Lymphoma } & NHL & 5 & \multirow{3}{*}{8} \\
\hline & Hodgkin`s & 2 & \\
\hline & CNS & 1 & \\
\hline U bladder & & 5 & 5 \\
\hline $\begin{array}{l}\text { Larynx \& Supra- } \\
\text { glottis }\end{array}$ & & 4 & 4 \\
\hline Prostate & & 3 & 3 \\
\hline \multirow{2}{*}{ Bones } & Hard palate & 1 & \multirow{2}{*}{2} \\
\hline & Mandible & 1 & \\
\hline Testis & & 1 & 1 \\
\hline
\end{tabular}

\begin{tabular}{|c|c|c|c|}
\hline Lung +CLL & 1 & 1 \\
\hline Lung +NHL & 1 & 1 \\
\hline $\begin{array}{c}\text { Primitive } \\
\text { peripheral } \\
\text { neuroectodermal } \\
\text { tumour }\end{array}$ & 1 & 1 \\
\hline \multicolumn{2}{|c|}{ Total } & 125 \\
\hline \multicolumn{3}{|c|}{ Table 2. Distribution of Patients as per types of } \\
Malignancy
\end{tabular}

Dermatological adverse effects of varying duration after initiation of anticancer drugs were found in 27 patients (21.6\%), 17 females and 10 males, with overall 45 side effects manifestation, as some patients developed more than one type of side effect in the same patient. 15 patients were in the age group 41-60 years, 8 in $\geq 61$ years and 4 in 21-40 years age group. This is summarised in Table 1 .

Most common cutaneous side effect which developed in 10 patients after varying duration of starting chemotherapy was alopecia, both anagen and telogen effluvium, with multiple drugs as suspected causative gents.

Diffuse hyperpigmentation, Xerosis and Hand-foot syndrome, developed in 4 patients each.

Erythema multiforme, lichenoid eruption, acneiform eruption and photosensitivity was seen in 2 patients each. 1 patient each had vasculitis, flagellate pigmentation, bullous eruption, and peeling of palms and soles.

6 patients had nail discolouration, with 4 developing leukonychia, both punctate and band like, and 2 having diffuse nail plate hyperpigmentation. Beau's line and Onycholysis developed in 1 patient each.

Oral mucositis in the form of erosions and erythema of the buccal mucosa developed in 3 patients.

All these dermatological adverse effects developing in relation to therapeutic agents for various types of malignancies are summarised in Table 3 , also depicting that some patients developed more than one type of side effect and also a particular anticancer drug gave rise to many dermatological manifestations. Table 4 mentions the side effects ascribed to individual chemotherapeutic agents.

\begin{tabular}{|c|c|c|c|c|}
\hline & $\begin{array}{c}\text { Side } \\
\text { Effects }\end{array}$ & \begin{tabular}{|l} 
No. of \\
Patients \\
$(n=27)$
\end{tabular} & $\begin{array}{c}\text { Possible } \\
\text { Culprit } \\
\text { Drug }\end{array}$ & $\begin{array}{c}\text { Type of } \\
\text { Malignancy }\end{array}$ \\
\hline 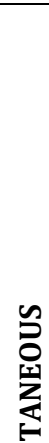 & Alopecia & 10 & \begin{tabular}{|c|} 
Cisplatin; Etoposide; \\
Bleomycin; \\
Cyclophosphamide, \\
Doxorubicin, \\
Vincristine; 5- \\
Flourouracil+ \\
Epirubicin; Paclitaxel; \\
Vinblastine, \\
Dacarbazine; \\
Carboplatin; \\
Ifosfamide; Docetaxel, \\
Oxaliplatin;
\end{tabular} & $\begin{array}{l}\text { Oesophagus } \\
\text {; Testis; } \\
\text { NHL; } \\
\text { Breast; } \\
\text { Hodgkin's; } \\
\text { Ovary; } \\
\text { Pleural } \\
\text { cavity } \\
\text { sarcoma; } \\
\text { Gastric; }\end{array}$ \\
\hline & $\begin{array}{c}\text { Diffuse } \\
\text { Pigmentation }\end{array}$ & 4 & \begin{tabular}{|c|} 
Doxorubicin+ \\
Cyclophosphamide; \\
paclitaxel; 5- \\
Flourouracil+ \\
Epirubicin; Docetaxel, \\
Oxaliplatin; imatinib \\
\end{tabular} & $\begin{array}{c}\text { Breast; } \\
\text { gastric; CML }\end{array}$ \\
\hline & Xerosis & 4 & Imatinib; Erlotinib & $\begin{array}{l}\text { CML; Adeno } \\
\text { Ca Lung; }\end{array}$ \\
\hline & Hand-foot & 4 & Doxorubicin+ & Breast; \\
\hline
\end{tabular}




\begin{tabular}{|c|c|c|c|c|}
\hline & syndrome & & $\begin{array}{l}\text { Cyclophosphamide; } \\
\text { Paclitaxel; } \\
\text { Trastuzumab; } \\
\text { Arsenic; ATRA*; } \\
\text { Mitomycin; } \\
\text { capecitabine; } \\
\text { Imatinib } \\
\end{array}$ & $\begin{array}{l}\text { AML; Anal } \\
\text { canal }\end{array}$ \\
\hline & $\begin{array}{l}\text { Erythema } \\
\text { Multiforme }\end{array}$ & 2 & $\begin{array}{c}\text { Bendamustine; } \\
\text { Rituximab; } \\
\text { Gemcitabine; } \\
\text { Cisplatin } \\
\end{array}$ & $\begin{array}{c}\text { NHL; } \\
\text { Pancreas; }\end{array}$ \\
\hline & Lichenoid & 2 & $\begin{array}{l}\text { Pemetrexed; } \\
\text { Cisplatin; } \\
\text { Gemcitabine } \\
\end{array}$ & \begin{tabular}{|c|} 
Ca \\
$\begin{array}{c}\text { lung+CLL; U } \\
\text { bladder }\end{array}$ \\
\end{tabular} \\
\hline & $\begin{array}{l}\text { Acneiform } \\
\text { eruption }\end{array}$ & 2 & $\begin{array}{c}\text { Methotrexate; } \\
\text { Actinomycin D; } \\
\text { Gefitinib }\end{array}$ & \begin{tabular}{|c|} 
H Mole; \\
Adeno Ca \\
Lung; \\
\end{tabular} \\
\hline & $\begin{array}{l}\text { Photo- } \\
\text { sensitivity }\end{array}$ & 2 & $\begin{array}{l}\text { 5-Flourouracil+ } \\
\text { Epirubicin }+ \\
\text { Cyclophosphamide }\end{array}$ & Ca breast \\
\hline & \begin{tabular}{|l|} 
Vasculitis \\
\end{tabular} & 1 & Cisplatin & Ca cervix \\
\hline & \begin{tabular}{|c|} 
Flagellate \\
pigmentation
\end{tabular} & 1 & $\begin{array}{c}\text { Bleomycin; Cisplatin; } \\
\text { etoposide }\end{array}$ & Ca testis \\
\hline & Bullous & 1 & $\begin{array}{c}\text { Gemcitabine; } \\
\text { Cisplatin } \\
\end{array}$ & U bladder \\
\hline & $\begin{array}{c}\begin{array}{c}\text { Peeling hands } \\
\text { \& feet }\end{array} \\
\end{array}$ & 1 & $\begin{array}{c}\text { Paclitaxel; } \\
\text { carboplatin }\end{array}$ & Breast; \\
\hline 笔 & $\begin{array}{c}\text { Nail } \\
\text { discolouratio } \\
\mathrm{n}\end{array}$ & 6 & \begin{tabular}{|c|} 
Cisplatin; Etoposide; \\
Cyclophosphamide, \\
Doxorubicin, \\
Vincristine; 5- \\
Flourouracil+ \\
Epirubicin; Paclitaxel; \\
Carboplatin \\
\end{tabular} & $\begin{array}{c}\text { Oesophagus } \\
\text {; NHL; } \\
\text { Breast; } \\
\text { Ovary; }\end{array}$ \\
\hline $\mathbf{z}$ & Beau's line & 1 & \begin{tabular}{|c|} 
Doxorubicin+ \\
Cyclophosphamide; \\
paclitaxel
\end{tabular} & Breast \\
\hline & Onycholysis & 1 & $\begin{array}{l}\text { Doxorubicin, } \\
\text { Ifosfamide }\end{array}$ & $\begin{array}{l}\text { Sarcoma } \\
\text { pleural } \\
\text { cavity }\end{array}$ \\
\hline ¿্ّ & $\begin{array}{c}\text { Oral } \\
\text { Mucositis }\end{array}$ & 3 & $\begin{array}{c}\text { Doxorubicin, } \\
\text { Bleomycin, } \\
\text { Vinblastine, } \\
\text { Dacarbazine; } \\
\text { Cyclophosphamide; } \\
\text { Paclitaxel; Erlotinib }\end{array}$ & $\begin{array}{l}\text { Hodgkin's; } \\
\text { Breast; } \\
\text { Lung Adeno } \\
\text { Ca }\end{array}$ \\
\hline & Total & 45 & & \\
\hline
\end{tabular}

\begin{tabular}{|c|c|}
\hline Culprit Drug & $\begin{array}{c}\text { Type of Dermatological } \\
\text { Adverse Effects }\end{array}$ \\
\hline Actinomycin D & Acneiform eruption \\
\hline Arsenic & Hand-foot syndrome \\
\hline $\begin{array}{c}\text { ATRA (All-trans } \\
\text { retinoic acid) }\end{array}$ & Hand-foot syndrome \\
\hline Bendamustine & Erythema Multiforme \\
\hline Bleomycin & $\begin{array}{c}\text { Alopecia; flagellate pigmentation; oral } \\
\text { mucositis }\end{array}$ \\
\hline Capecitabine & Hand-foot syndrome \\
\hline Carboplatin & $\begin{array}{c}\text { Alopecia; Peeling hands \& feet; Nail } \\
\text { discolouration }\end{array}$ \\
\hline Cisplatin & $\begin{array}{c}\text { Alopecia; Erythema Multiforme; } \\
\text { Lichenoid; vasculitis; flagellate rash; } \\
\text { bullous; Nail discolouration }\end{array}$ \\
\hline Cyclophosphamide & Alopecia; diffuse pig; Hand-foot \\
\hline
\end{tabular}

\begin{tabular}{|c|c|}
\hline & $\begin{array}{l}\text { syndrome; photosensitivity; nail } \\
\text { discolouration; Beau`s line; oral } \\
\text { mucositis }\end{array}$ \\
\hline Dacarbazine & Alopecia; Oral mucositis \\
\hline Docetaxel & Alopecia; Diffuse pigmentation; \\
\hline Doxorubicin & $\begin{array}{l}\text { Alopecia; diffuse pigmentation; Hand- } \\
\text { foot syndrome; Nail discolouration; } \\
\text { Beau`s line; onycholysis; oral mucositis }\end{array}$ \\
\hline Epirubicin & $\begin{array}{c}\text { Alopecia; diffuse pigmentation; } \\
\text { Photosensitivity; Nail discolouration }\end{array}$ \\
\hline Erlotinib & Xerosis; Oral mucositis \\
\hline Etoposide & $\begin{array}{l}\text { Alopecia; flagellate pigmentation; Nail } \\
\text { discolouration }\end{array}$ \\
\hline 5-Fluorouracil & $\begin{array}{c}\text { Alopecia; diffuse pigmentation; } \\
\text { Photosensitivity; Nail discolouration }\end{array}$ \\
\hline Gefitinib & Acneiform eruptions \\
\hline Gemcitabine & Erythema Multiforme; Lichenoid; Bullae \\
\hline Ifosfamide & \begin{tabular}{|l|} 
Alopecia; Onycholysis \\
\end{tabular} \\
\hline Imatinib & $\begin{array}{l}\text { Diffuse pigmentation; Xerosis; Hand- } \\
\text { foot syndrome }\end{array}$ \\
\hline Methotrexate & Acneiform eruption \\
\hline Mitomycin E & Hand-foot syndrome \\
\hline Oxaliplatin & Alopecia; Diffuse pigmentation; \\
\hline Paclitaxel & $\begin{array}{l}\text { Alopecia; diffuse pigmentation; HF } \\
\text { syndrome; Peeling hands \& feet; Nail } \\
\text { discolouration; Beau`s line; oral } \\
\text { mucositis }\end{array}$ \\
\hline $\begin{array}{c}\text { Premet } \\
\text { (Pemetrexed) }\end{array}$ & Lichenoid \\
\hline Rituximab & Erythema Multiforme \\
\hline Trastuzumab & Hand-foot syndrome \\
\hline Vinblastine & Alopecia; Oral mucositis \\
\hline Vincristine & Alopecia; Nail discolouration \\
\hline \multicolumn{2}{|c|}{$\begin{array}{c}\text { Table 4. Dermatological Adverse Effects Related to } \\
\text { Individual Drugs (Alphabetical Order) }\end{array}$} \\
\hline
\end{tabular}

In this study, in none of the cases was the drug withdrawn or changed, and the dermatological manifestations were managed simultaneously.

Figures 1-5 represent the clinical pictures of some of the dermatological adverse effects noticed in our study.

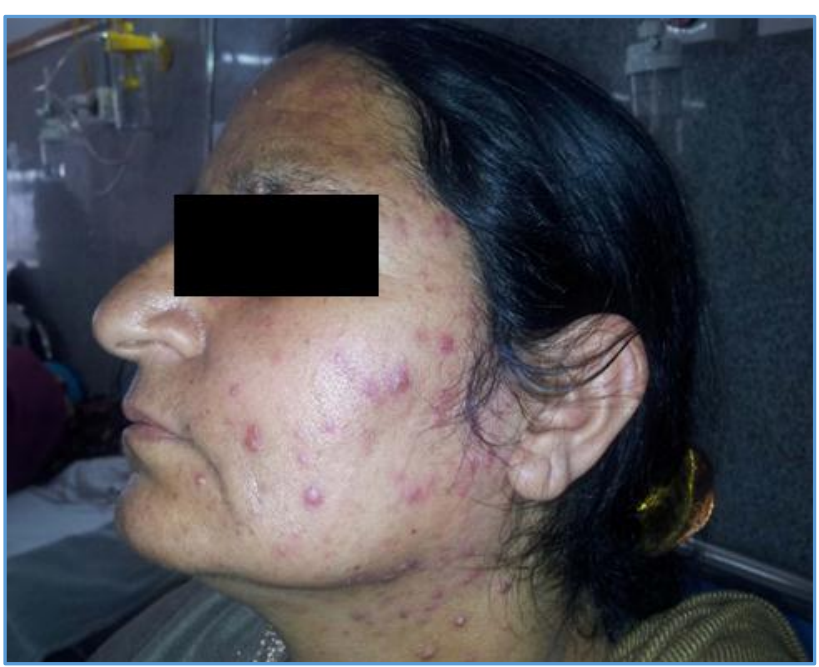

Figure 1. Acneiform Eruption 


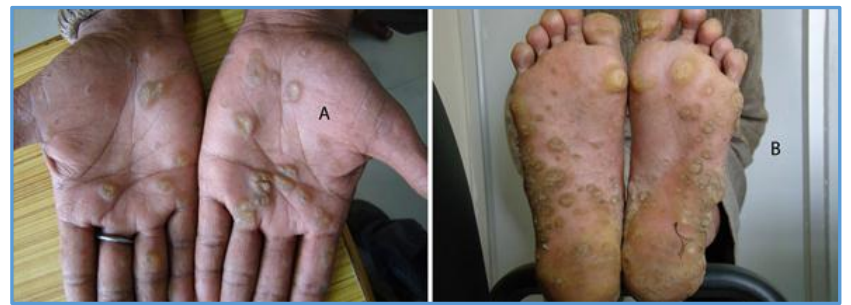

Figure 2. Arsenic Keratosis

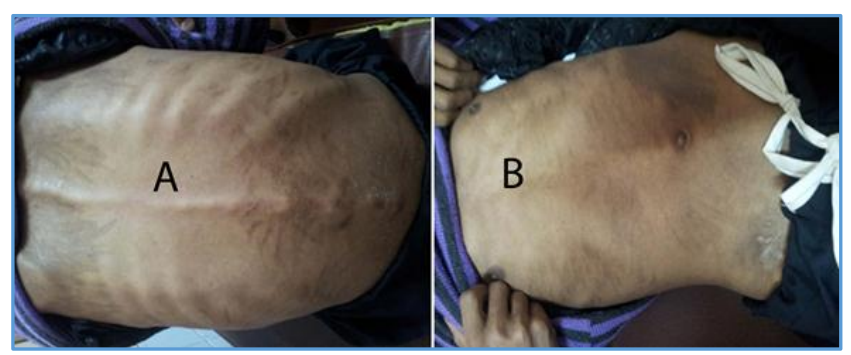

Figure 3. Flagellate Pigmentation

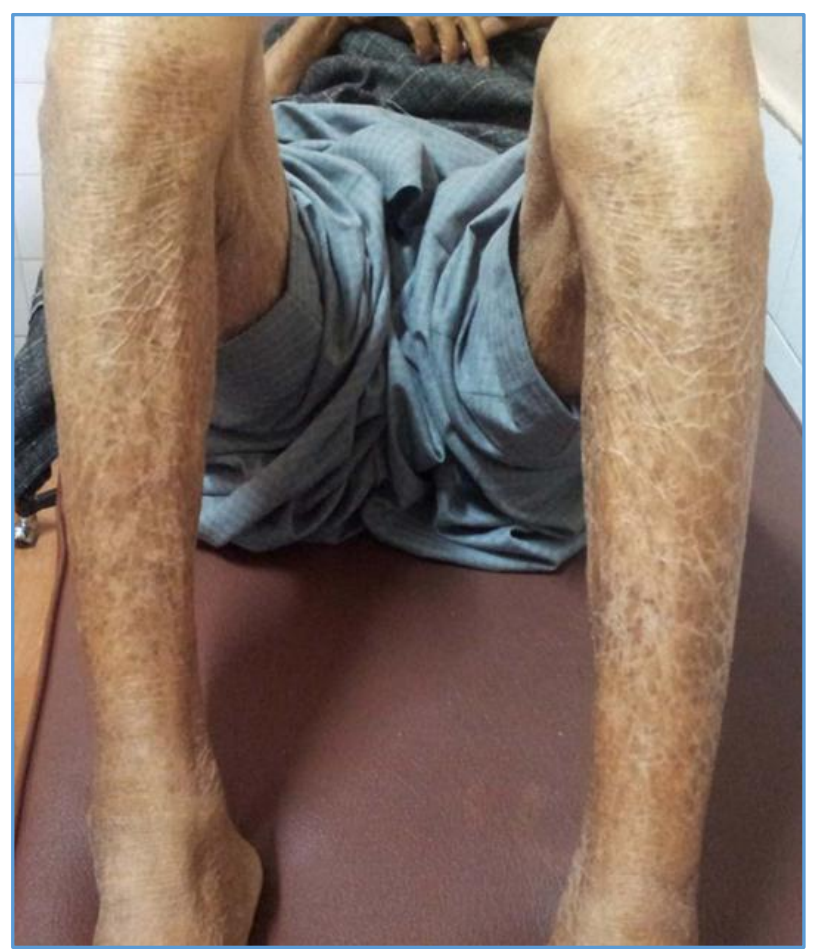

Figure 4. Acquired Ichthyosis

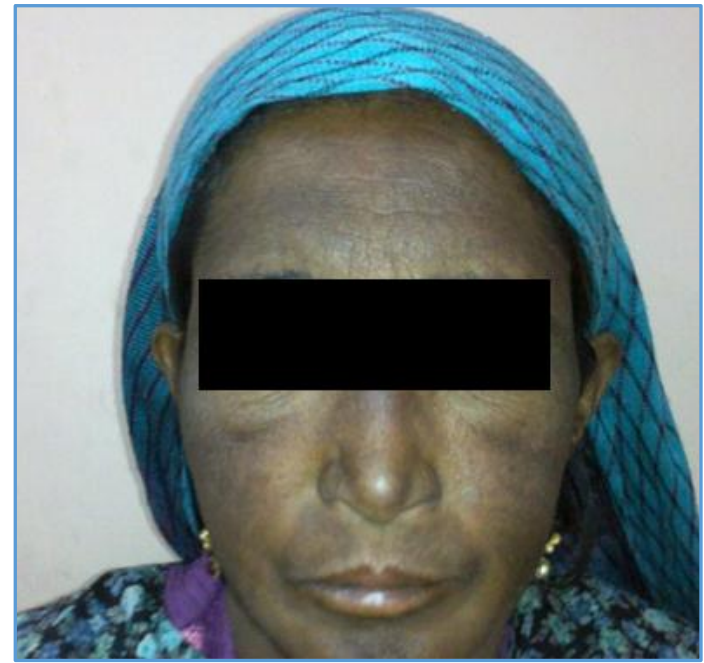

Figure 5. Diffuse Facial Pigmentation

\section{DISCUSSION}

New anticancer drugs developed over the last few decades have improved the survival rate in cancer patients. Traditional chemotherapy drugs as well as the newer targeted agents are associated with a wide array of cutaneous toxicities. Toxic effects on skin, hair and nails are generally mild to moderate in severity, but may negatively affect the quality of life and lead to treatment delays, dose modifications and discontinuation of therapy. At the same time, presence and severity of rash may be an indicator of tumour response as well as overall survival.

Anti-cancer drugs usually affect rapidly growing cells and hence, the skin, hair follicles and nail matrix are the frequent targets of their toxicities. Clinically distinct patterns of cutaneous adverse events can be observed from alteration of the normal function of these structures. Various anti-cancer drugs such as epidermal growth factor receptor (EGFR) inhibitors including cetuximab and gefitinib, multikinase inhibitors (Imatinib, sorafenib), taxanes (Paclitaxel), vinca alkaloids (Vincristine, vinblastine), antimetabolites (6-mercaptopurine, 5-fluorouracil, Cytarabine, capecitabine, gemcitabine), genotoxic agents (Cisplatin, carboplatin, oxaliplatin, etoposide, cyclophosphamide, and anthracyclines like doxorubicin, daunorubicin, epirubicin), hydroxyurea, cyclophosphamide, doxorubicin, vincristine, prednisolone (CHOP) and ABVD (Doxorubicin, bleomycin, vinblastine, dacarbazine) regimens are associated with prominent and sometimes dose-limiting dermatologic complications.

In this study, $21.6 \%$ of the patients developed dermatological adverse effects, some with more than one manifestation, and mostly being in the age group 41-60 years.

Among all the cutaneous manifestations, most common ones were anagen and telogen effluvium, followed by diffuse hyperpigmentation, xerosis and hand-foot syndrome. In some previous studies also, alopecia was the most common adverse effect noted..$^{3,4}$

Chemotherapeutic agents used in cancer chemotherapy frequently cause alopecia, with anagen effluvium being the most common pattern and it usually begins in 1-2 weeks after starting the drug, becoming more apparent in the subsequent 4-8 weeks. The mechanism involved is a sharp fall in mitotic activity of the matrix cells of the hair follicle due to cytotoxicity. Drugs like doxorubicin, daunorubicin, docetaxel, and cyclophosphamide are more likely to cause anagen effluvium. Hair loss has been rated as one of the most distressing side effects of chemotherapy.

In our study, Cisplatin, Etoposide, Bleomycin, Cyclophosphamide, Doxorubicin, Vincristine, 5-Flourouracil, Epirubicin, Paclitaxel, Vinblastine, Dacarbazine, Carboplatin, Ifosfamide, Docetaxel, Oxaliplatin, were responsible for alopecia, as also in previous studies. ${ }^{1,5}$

Hyperpigmentation has been reported to occur with anticancer drugs, which may be in the form of diffuse or localised involvement of the skin. The mechanism remains unknown, but it is postulated to be due to accumulation of drug in skin or a direct toxic effect on melanocytes stimulating increased melanin production or elevated adrenocorticotropic hormone and melanocyte stimulating hormone. The drugs commonly causing pigmentation are cyclophosphamide, hydroxyurea, doxorubicin, cisplatin, fluorouracil, etoposide, busulfan, and bleomycin. Cutaneous toxicity classically known to present with bleomycin are flagellate erythema and pigmentation. 
Along with cutaneous pigmentation, longitudinal and transverse bands or diffuse nail pigmentation and patchy pigmentation of tongue and buccal mucosa may also occur.

In our study, we saw generalised hyperpigmentation of most of the body, both covered and exposed skin areas, results being consistent with some previous studies. ${ }^{1,6}$

EGFR inhibitors have been shown to cause xerosis with associated asteatotic eczema. Older age of patients with malignancy can have an additive effect on dryness caused by this class of drugs. Epidermal growth factor is necessary for maintaining the epithelial barrier function. Accumulation of drug in the eccrine sweat units could lead to disturbance in their secretory function and thereby could explain the dryness of the skin.

Xerosis of whole body including face and scalp was also a significant occurrence in our study, especially attributed to Imatinib and Erlotinib, epidermal growth factor receptor inhibitors, similar to that in previous studies.7,8

Hand-foot syndrome represents the clinically significant and occasionally dose-limiting skin toxicity of Cytarabine, doxorubicin, 5-fluorouracil, sorafenib, and sunitinib. Dual inhibition of vascular endothelial growth factor receptor (VEGFR) and platelet-derived growth factor receptor (PDGFR) disrupts the normal repair process involving capillaries and fibroblasts. This blockade, in combination with repeated subclinical trauma and friction to areas such as palms and soles, leads to inflammation. The characteristic cutaneous presentations in Hand-foot syndrome are symmetric acral blisters with erythematous halo, hyperkeratosis followed by desquamation and fissuring. It involves the palmar aspect of digital tips, thenar, hypothenar eminences, heel and forefoot.

In our study, hand-foot syndrome was seen in patients on Doxorubicin, Cyclophosphamide, Paclitaxel, Trastuzumab, Arsenic, All-trans retinoic acid, Mitomycin, capecitabine. Similar type of hand-foot syndrome occurrence with targeted therapies was also seen in previous studies. 1,9,10,11

Other cutaneous effects in our study such as erythema multiforme, lichenoid eruption, acneiform eruption, photosensitivity, and less frequent ones such as vasculitis, flagellate pigmentation, bullous eruption, and peeling of palms and soles, were also seen, as noticed in previous studies. 1,2,4,5,6,12,13

Among the chemotherapeutic agents, epidermal growth factor receptor inhibitors are associated with intensely itchy papulopustular rash or acneiform eruptions that occur mainly on the seborrheic areas such as the face, scalp and chest. It is hypothesised that the action of the drug alters signalling pathways resulting in keratinocyte growth arrest, apoptosis, decreased cell migration and increased differentiation and elicits an inflammatory response mediated by various cytokines released from keratinocytes. The pathophysiology of acneiform eruption is poorly understood. EGFR is commonly expressed in the pilosebaceous unit, both in follicular keratinocytes and in sebocytes. It has been postulated that both EGFR overstimulation and inhibition lead to disorganisation of the pilosebaceous unit and influx of proinflammatory sebum into the dermis.

Nail matrix cells are continuously dividing cells that are frequently affected by chemotherapy leading to cosmetic nail disfigurement.
Nail discolouration was the most notable nail change in our study, with leukonychia being more common than hyperpigmentation. Beau's line and onycholysis were found in 1 patient each. Similar types of nail changes, with some variations were noted in most of the previous studies. ${ }^{1,6,8}$

Mucosal manifestations associated with chemotherapy are common but not well known, as physicians being concerned more with the anti-tumour efficacy of the treatment and other serious systemic adverse effects, often tend to underestimate them.

Most common oral mucosa manifestation was oral mucositis, similar to previous studies. ${ }^{1,6,7}$

\section{CONCLUSION}

Dermatological side effects related to chemotherapeutic agents is common but timely recognised, being a visible occurrence most of the times. Although this creates an alarming apprehension among the treating physician as well as the patients and their attendants, yet most of the times, the features are not of such serious nature as to warrant withdrawal or changeover of the therapy. But a thorough knowledge is essential to alleviate such an apprehension and avoid a wrong decision.

\section{Limitations}

A particular side effect manifestation was caused by combination drugs, and individual culprit drug could not be identified with certainty. Similarly, a single drug or combination of drugs resulted in more than one dermatological manifestations.

\section{REFERENCES}

[1] Pavey RA, Kambil SM, Bhat RM. Dermatological adverse reactions to cancer chemotherapy. Indian J Dermatol Venereol Leprol 2015;81(4):434.

[2] Susser WS, Whitaker-Worth DL, Grant-Kels JM. Mucocutaneous reactions to chemotherapy. J Am Acad Dermatol 1999;40(3):367-98.

[3] Kamil N, Kamil S, Ahmed SP, et al. Toxic effects of multiple anticancer drugs on skin. Pak J Pharm Sci 2010;23(1):7-14.

[4] Chiewchanvit S, Noppakun K, Kanchanarattanakorn K. Mucocutaneous complications of chemotherapy in 74 patients from Maharaj Nakorn Chiang Mai hospital. J Med Assoc Thai 2004;87(5):508-14.

[5] Hinds G, Thomas VD. Malignancy and cancer treatment-related hair and nail changes. Dermatol Clin 2008;26(1):59-68.

[6] Garg T, Sanke S, Yadav P, et al. Mucocutaneous manifestations in patients on chemotherapy with pediatric haematological malignancies. Astrocyte 2016;3(2):74-7.

[7] Chanprapaph K, Pongcharoen P, Vachiramon V. Cutaneous adverse events of epidermal growth factor receptor inhibitors: a retrospective review of 99 cases. Indian J Dermatol Venereol Leprol 2015;81(5):547.

[8] Madke B, Gole P, Kumar P, et al. Dermatological side effects of epidermal growth factor receptor inhibitors: pride complex. Indian J Dermatol 2014;59(3):271-4. 


\section{Jemds.com}

[9] Balagula Y, Lacouture ME, Cotliar JA. Dermatologic toxicities of targeted anticancer therapies. J Support Oncol 2010;8(4):149-61.

[10] Heidary N, Naik H, Burgin S. Chemotherapeutic agents and the skin: an update. J Am Acad Dermatol 2008;58(4):545-70.

[11] Pragasam V, Verma R, Vasudevan B. Sorafenib and sunitinib: a dermatologist's perspective. Indian Dermatol Online J 2014;5(1):1-3.

\section{Original Research Article}

[12] Nakatani K, Matsumoto $M$, Ue H, et al. Erythema multiforme after radiotherapy with aromatase inhibitor administration in breast-conservation treatment for breast cancer. Breast Cancer 2008;15(4):321-3.

[13] Ghosh SK. Generalized lichenoid drug eruption associated with imatinib mesylate therapy. Indian Journal of Dermatology 2013;58(5):388-92. 